\title{
Modern Phase \\ of Cultural-Historical Psychology: \\ Path of Development
}

\author{
Boris D. El'konin* \\ Psychological Institute \\ Russian Academy of Education
}

Build. 4, 9 Mokhovaya Str., Moscow, 125009, Russia

Received 19.09.2015, received in revised form 29.09.2015, accepted 02.11.2015

The article introduces the current view on the intentional object of cultural-historical and pragmatism theories, the object being the intermediary action. The intermediary action is the act of development with supports of activity being its result, the activity field being its effect, and the meaning of a psychological tool being its product.

Keywords: mediation, psychological tool, intermediary action, meaning, development.

DOI: 10.17516/1997-1370-2015-8-11-2743-2748.

Research area: pedagogy, psychology.

What is great in man is that he is a bridge and not a goal...

F. Nietzsche "Thus Spoke Zarathustra"

\section{What did Cultural-Historical} Psychology overcome?

- "Psyche per se" was the intentional object of psychology of the XIX and early XX centuries. The challenge of this psychology is classically scientific research of the psyche. The psyche was understood and analyzed as a source of an individual's activity existing "in" him / her (Apperception, Will). The result of the activity itself was viewed and analyzed as Representation which is the vision (assumption) of something exterior to oneself ${ }^{1}$.
The behaviorists viewed the activity of living beings (and humans in particular) as the reaction to stimuli. This assumption was repeatedly criticized. However, while accepting this criticism, it is important to note that it was for the first time when what was previously called the psyche was implicitly presented as a particular way of existing in the World as the world of stimuli of different strength. This view resulted in a new discourse, that of assumption of some "element" that can take its place in the World. In their polemics with the behaviorists the Gestalt psychologists defined the World as the world

(C) Siberian Federal University. All rights reserved

* Corresponding author E-mail address: belconin@bk.ru 
of open structures and, thus, they specified the place of activity as the act, closing the structure and overcoming "functional fixedness of past experience".

- Cultural Event, called "L.S. Vygotsky's cultural-historical conception", is associated with three phrases. Now they seem to be longfamiliar "common places" though, which is great thoughtlessness. These are "overcoming of natural in cultural", "psychological tool", "transition of inter-psychic form in intra-psychic one". I will try to give their interpretation, taking advantage of considering Vygotsky's view and the situation after him up to the contemporary one. It should be specifically mentioned that the situation nowadays is the situation of the developments carried out by the 4 th generation of the Cultural-Historical Conception ${ }^{2}$ followers. This generation's problem field is likely to be the image of a new possible and, at the same time, necessary cycle of works.

- "Overcoming of natural in cultural" implies the mode of presence, i.e. occupying the place by Consciousness and Psyche: Consciousness and Psyche are not present "somewhere" but come out, emerge only at a certain force, action (and reconstruction of this "x-action"). The latent form of its existence which has already turned into and "got control over" the behavior is an element of the natural that can have different "guises" - molecularly informational (gene) one, stimulus one, the form of regulatory direction ("cultural"). Natural behavior is the behavior embedded in some form beyond the action or in the latency of action of embedding. Discovery and shaping the form of one's behavior is the Act of Development.

- "Psychological tool" suggests that "culture" and "meaning" $"{ }^{3}$ are present in the behavior only as modes to overcome the latent behavior determinants, modes of transition to arbitrariness that is shaping of forms of behavior by the individual him/herself. Views, knowledge have changed the place of the activity result (the place they had in classical psychology) to that of the mode of construction and reconstruction of this activity. This is the point of the key issue of how the subject of activity is built by means of meaning. It arises in the place of common judgment that denotatum is in the meaning.

- The judgment about the "transition of inter-psychic form in intra-psychic one" implies that the original "place" of the psyche is not "in" individuals but in their treatment of each other by means of "psychological tool". Thus, it is assumed that the psyche and consciousness cannot be incumbent (known) by a distant observer and require the Other's active participation in their detection (objectivation). This is the requirement to the methods of "double stimulation", constituting the core of the "experimental-genetic method" of research. It is this method that "nonclassical psychology" (D.B. El'konin) is based on. At the point of experimental genesis construction there arises the issue of the conditions under which the "experimenter" is actually present in the "subject's" behavior, finds his place in him / her and thus finds him / her so that his "communication" turns into "psychological tool" which is the support of the subject's searching and testing of the form of his / her activity.

\section{Meaning and action}

- The works of the representatives of the second generation can be regarded as focused on determination and consideration of the conditions of "psychological tool" formation. Formation of the "external, object action" by the individual (the subject of the experimental genesis) was such a condition. The object action, however, was separated from the meaning (word) and the meaning is presented as "secondary", derived from action. Thus, the conception got its gnoseological sounding. 
- In experimental studies of the "Kharkov group" the meaning meant to be a result of assimilation to the "logic of the tool", and the real tool was the original "psychological tool" to the extent an individual acts "according to the logic of the tool" overcoming "the logic of hands" (P.Ia. Gal'perin).

- In A.N. Leontiev and his staff's wellknown experimental research on the genesis of senses and pitch hearing formation the focus of attention shifted once again. It is now on the object action and representation (senses, perception). It was shown that the object action is initial in the image formation, though it is initial only in cases of active attempts to assimilate the image of the object. In these attempts the subjects' new "functional organs" were formed, the latter serving for feeling either latent or hardly reconstructed reality. Recalling L.S. Vygotsky's logic and focuses made and transforming gnoseological modus to ontic one, it can be argued that the very corporeity of the individual was built as "the psychological tool". Thus, the individual's psycho-physiological system acted as the Mode - the mode of the latent phenomenon and, thus, the mode of building a new field of possible action.

- For A.V. Zaporozhets the condition for voluntary action is its transformation in the perceived movement, i.e. acquisition of interoceptive ("intramuscular") sense of selfmotion by the individual. A.V. Zaporozhets' and M.I. Lisina's remarkable experiments reconstructed the emergence of such "internal" senses and control over them. Linking this discovery with the interpretation of A.N. Leontiev's experiments, it can be argued that the individual's psycho-physiological system becomes a psychological tool if external and internal movements ${ }^{4}$, extero- and interoception are connected. What connects them?
A brief analysis of "knots" of the theory of action can be completed with three key questions.

1. What is inter-psychic form of activity according to A.N. Leontiev's key researches? There is no place for the experimenter's actions during the experiment in the protocols and descriptions of the experiments. He is present as the situation Creator, moving sideways when the subject is involved in the situation. Accordingly, in interpretations and conclusions the action was attributed to the subject either directly and sometimes by default as if it "belonged" to him. So, is it the individual's action but not "inter-psychic form" which is meant when "action" is mentioned? In A.V. Zaporozhets and M.I. Lisina's experiment the focus of attention is different. The experiment's turning point, leading to its success, is the point when the subject is shown the oscilloscope screen with the note, the "picture" of dynamics of his / her "inner corporal" reactions; the experimenter's screen is turned to the subject. However, in their analysis and conclusions both A.V. Zaporozhets and A.N. Leont'ev attribute the action to the subjects. At the same time "social nature" of both the psyche and the activity are dwelt upon in all the texts of the representatives of the second generation. The Other's work seems to be perceived as something self-evident, not requiring special analysis and therefore it was factored out, there was no place for it in the activity under the research. Though it was the experimenter (the Other) who formed the subject's Field of activity, "the field of the manner of the action", according to P.Ia. Gal'perin.

2. Judgments about categorial nature of Motive, Purpose and Meaning take a significant place in the texts of the representatives of the second generation. However, these entities were not reconstructed as specific phenomena in key experimental research. There may emerge the 
impression that the motive and purpose are some representations, "added" from the outside to the beginning and completion of the individual activity, to its transitional "points". What is the content of Action on initiation, i.e. on the transition to the fulfillment and on the transition to the completion? How does it relate to the content of "the individual's action"?

3. The analysis of texts written by the representatives of the second generation as well as by Vygotsky himself leads to the idea of fluctuations of the Object of the researches. On the one hand, it is a "classic" object - an image, thought, i.e. "psychic phenomena". It is their experimental genesis that is built in one way or another. However, the discussion of Vygotsky's followers with their Teacher and their experimental research "hide" another entity, the Act of Mediation. Yet, it is hidden but not seen - it is "in the shadow" of assumption.

\section{Shift of the Object of the research}

- The date of transition to the research of the mediation act and, thereby, regarding this act as the Object of the research, to my mind, is the date of publication of D.B. El'konin's article "Zametki o razvitii predmentnykh deistvii v rannem detstve" ("Notes on object actions development in early childhood"). This focus received its continuation in my works. The key methodological position and meaning of these works are in the following: it is the Act of Mediation, i.e. Intermediary Action that is the Intentional Object of modern CulturalHistorical Psychology. Intermediary Action (IA) develops in ontogenesis as the connectedness of Events in the community of children and adults. What should undergo the research and be experimentally reconstructed are the conditions of the Intermediary action.

- In IA the meaning (word) and acting itself are simultaneous (and, therefore, the matter does not involve the relationship of the priority and the secondariness). The "turning point" of the child's behavior (e.g., its boundary) is prominent in the adult's word ${ }^{5}$, whereas the children state the meaning and sense of the adult's word of appeal by their corporeity and thereby state the very situation of reciprocity commonness of target entities. Effective use of the word of appeal is Practice of Meaning. This is the beginning of turning the activity into Action, one's own Action and turning the word into Psychological Tool.

- Later the adult's word becomes the child's own Support and the Image of Action is formed. And then, when support is tested and reconstructed as the rhythm of the Elements of his / her own aspirated movement, the Field of action is formed. At this period the child begins to distinguish his / her action from the action with him (dressing, washing, etc.) ${ }^{6}$ and try the "scope" of the field of his / her action. The meaning is formed and mastered in the "collisions" of the word with the physical activity (but not in the "anticipation" of the word by "external objective" manipulations). So, the Collective Intermediary Action is the action with the child's fulfillment of a certain instruction being its result, construction and familiarization with the situation of action (the boundaries of intentions) being its effect, and formation and mastering the meaning that specifies the image of the "contour" of the field of action being its product.

- The last question, concerning IA, is the following: "Why is Mediation as building one's own supports and formation of one's own field of action necessary? L.S. Vygotsky and his followers' answer is clear: we need mediation as a mode of cultivating Arbitrariness of human activity, i.e. a human's genuine independence and initiative, the latter being the characteristic features of Free action (V.P. Zinchenko). Yet, 
what would be the case if, wording it the way Husserl did, cultural and value assumptions of the importance and necessity of independence, initiative and freedom were "factored out"? Upon performing this procedure, we face a strange question, and namely "What kind of a "feeding" mode are arbitrary and free actions proper? What do they "feed"?". This is the point at that the transition to ultimate existential characteristics of human practice is needed.

- In one of the articles, with reference to A.V. Zaporozhets' and M.I. Lisina's experiments, I wrote that Mediation is screening (strengthening, mapping and returning) of internal perception of another individual 7 . This is the task of the meaning of a psychological tool. This task is performed in cases when the "agent" him / herself returns the meaningful content, as if "screening it back". $\mathrm{He} /$ She selects, strengthens, and focuses its transitional rhythms by his / her corporeity. Thus, he / she strengthens and makes its Form explicit (like, for example, the measured tread strengthens the elegance of march). Such exchanges are life energy intensifiers. As intensifiers they are possible only as reconstructions of a screenmeaning, i.e. as arbitrary actions. Strengthening and reconstruction of the energy of life are the ultimate existential task of Mediation.

\footnotetext{
It is worth while refreshing S. Freud's conception (and psychoanalysis as such), dwelling on "psychic energy" - the energy flowing "outside" the psyche, "driven" in the unconscious.

2 Professional generations are meant. The 1st generation is Vygotsky himself and, consequently, the Conception (object and method) of new psychology; the $2^{\text {nd }}$ generation is A.N. Leont'ev, A.R. Luriia, A.V. Zaporozhets, P.Ia. Gal'perin, D.B. El'konin, et al.), who surmounted the conception in the Project while debating with the Teacher (and all the realities of their century); the $3^{\text {rd }}$ generation is their followers (V.V. Davydov, V.P. Zinchenko, L.S. Tsvetkova, Iu.B. Gippenreiter, et al.), who worked out the Programmes of project implementation (in developmental psychology, general psychology, ergonomics, neuropsychology).

3 Special analysis is needed for the evolution of Vygotsky's understanding of meaning from "Psychology of art" via "History of higher mental functions development" to Chapter VII "Thinking and speech".

4 “Internal movement" is A.V. Zaporozhets' term introduced at the description of works on rehabilitation of wounded soldiers' movements (Re.: Leont'ev A.N., Zaporozhets A.V. "Movement rehabilitation”. Moscow, 1945).

5 That is why the word is not "the association" of a sound with an object but the medium of its selection, making it explicit and turning it into a psychological tool.

6 С этим, подчас конфликным, отличением и связана Интериоризация (индивидуализация).

7 В статье «Действие как единица развития» (Вопросы психологии №1, 2004, а также в кн. «Опосредствование. Действие. Развитие»)
}

\section{References}

El'konin B.D. Oposredovanie. Deistvie. Razvitie. [Mediation. Action. Development]. Izhevsk, ERGO, 2010. 279 p.

El'konin B.D. (2014). Sobytie deistviia (Zametki o razvitii predmetnykh deistvii II) [The event of action (Notes on the development of object actions II)]. Cultural-Historical Psychology, $1,11-19$.

El'konin D.B. (2013). Chuvstvo sobstvennoi aktivnosti v osvoenii poniatiia (eksperimental'noe issledovanie) [A sense of own activity in mastering the concept (experimental research)]. “Antropopraksis". Ezhegodnik gumanitarnykh issledovanii, 94-104.

El'konin D.B. Izbrannye psikhologicheskie trudy [Selected psychological works]. Moscow, Pedagogics, 1989. 555 p.

Gal'perin P.Ia. Psikhologiia kak ob'ektivnaia nauka [Psychology as objective science]. Moscow, Institute of practical psychology, Voronezh, Modek, 1998. 480 p.

Husserl E. Krizis evropeiskikh nauk i transtsendental'naia fenomenologiia [Crisis of European sciences and transcendental phenomenology]. St.Petersburg, Vladimir Dal', 2004. 398 p. 
Leont'ev A.N. Problemy razvitiia psikhiki [Problems of the development of psyche]. Moscow University, 1981. 584 p.

Nezhnov P.G. (2007). Oposredovanie i spontannost' v modeli "kul'turnogo razvitiia" [Mediation and spontaneity in the model of "cultural development"]. MSU Vestnik. Psychology, 1, 133-146.

Vygotsky L.S. Sobranie sochinenii: v 6 t. [Collected works: in 6 vol.]. Moscow, Pedagogy, 19821984.

Vygotsky L.S. Psikhologiia iskusstva [Psychology of art]. Moscow, Iskusstvo, 1968. 576 p.

Zaporozhets A.V. Razvitie proizvol'nykh dvizhenii [Development of arbitrary movements]. Moscow, Publishing House of Academy of Pedagogical Sciences of the RSFSR, 1960. 429 p.

Zinchenko V.P. Soznanie i tvorcheskii akt [Consciousness and the creative act]. Moscow, Languages of Slavic cultures, 2010. 592 p.

\title{
Современный этап
}

\section{культурно-исторической психологии: \\ направление разработок}

\author{
Б.Д. Эльконин \\ Психологический институт \\ Российской академии образования \\ Россия, 125009, Москва, ул. Моховая, 9, стр. 4
}

В статье вводится современное представление об интенщиональном объекте культурноисторической и деятельностной теорий. Таким объектом представляется посредническое действие. Посредническое Действие, результатом которого становятся опоры активности, эффектом - поле активности, а продуктом - значение психологического орудия, есть акт развития.

Ключевые слова: опосредствование, психологическое орудие, посредническое действие, значение, развитие

Научная специальность: 13.00.00 - педагогические науки, 19.00.00- психологические науки. 